\title{
A Study of the Development of Accounting Higher Education in Brazil: A View of graduation to the Doctorate
}

\author{
Marcia Helena de Andrade ${ }^{1}$, Fernando Silva Lima ${ }^{2}$, Gustavo Henrique Silva Santana ${ }^{3}$ \& Kaique Felipe da Cruz \\ Rabelo $^{3}$ \\ ${ }^{1}$ Master of Business Administration. Professor at the State University of Goiás (UEG), Brazil \\ ${ }^{2}$ Master in Regional Development. Professor at the Federal Institute of Education, Science and Technology of \\ Maranhão (IFMA) - Campus Bacabal, Brazil \\ ${ }^{3}$ Researcher at the State University of Goiás (UEG), Brazil \\ Correspondence: Fernando Silva Lima, Master in Regional Development, Professor at the Federal Institute of \\ Education, Science and Technology of Maranhão (IFMA)-Campus Bacabal, Avenida Governador João Alberto, \\ Areal Neighborhood, City of Bacabal, Maranhão State, Brazil.
}

Received: November 25, 2017

Accepted: December 13, 2017 Online Published: December 19, 2017

doi:10.5430/ijba.v9n1p14

URL: https://doi.org/10.5430/ijba.v9n1p14

\begin{abstract}
This study sought to address the development of accounting education in the Brazilian scenario. A methodology applied to the analytical method, however, with a quantitative and qualitative approach. The results showed that masters programs are more offered by public higher education institutions, a reality that is controversial for a graduate. The Research concludes that it is necessary to carry out a strategy and incentives to increase as vacancies in the Masters and Doctoral Programs in Brazil.
\end{abstract}

Keywords: post-graduation, stricto sensu, master, doctorate

\section{Introduction}

Iudícibus (2009, p.16) says that accounting "arose as an art of controlling the assets initially of the individuals passing to the control of commercial activities and finally considered as a science that seeks study while it was developing, It is thus, easy to understand, going over antiquity, why Accounting had its flourishing, as an adult and complete discipline".

The accounting had its world-wide expansion arriving at Brazil in the Colonial time, being the professional bookkeepers. Reis and Silva (2007) report that the accounting professional was known as bookkeeper in the past. After this, the accounting profession developed with the regulation of Law 3.384 / 58, which regulated bookkeeping in accounting technicians and with Decree Law no. 7,988 of September 22, 1945, who created the course of accounting of higher level in Brazil, with title of superior course of Economic Sciences and Accounting and Actuarial Sciences.

From these standards, accounting has grown in Brazil, being one of the first countries to have higher education in accounting, through the Álvares Penteado School of Commerce, as reported by Barros Leite (2005). Thus, the accounting profession was composed by Accounting Technician and Bachelor of Accounting. Subsequently, there was a change in this composition promoted by Law 12.249, of 2010, determined that, from 2015, only those who have Higher Education can obtain professional registration in Accounting.

Given this context, the postgraduate course in Accounting was highly sought after. Currently the Federal Accounting Council (2014) published a note stating that there are 500,000 active professionals in Brazil, of which 189,904 are technicians and 311,803 accountants. In 2013, 7,509,694 students enrolled in higher education courses, 7,305,977 in undergraduate courses and 203,717 in graduate programs, both with a very significant number of students and graduates, as can be seen in the development of the research.

The expansion of accounting education in undergraduate education was based on the strong governmental incentive of private higher education institutions, as Burton (2009) points out. But accounting higher education does not only materialize in undergraduate studies, there are postgraduates at the level of specialization (lato sensu) and masters 
and doctorates (stricto sensu), where research has identified different data, as presented by Bugarim (2014) "in Brazil at present there are 3,264 masters and 275 doctors in accounting".

In this sense, the main objective of this study was to demonstrate the development of accounting higher education in Brazil, and through this research it was possible to perceive a considerable expansion in undergraduate education and the reduced number of master's and doctoral programs, together with the number small number of vacancies offered in existing programs. This becomes a challenge and possibly an obstacle to those interested in continuing their studies in the accounting field and consequently the very low numbers of masters and doctors. In observing the Brazilian reality, a study was carried out with countries such as the United States, United Kingdom, Australia and Canada in the search for a better analysis. A comparison was made to show the difference in the number of Brazilian programs and the countries found, as a complementation it was questioned the opinion of the scholars in relation to the number of vacancies and Brazilian programs, thus allowing, to obtain significant considerations on the proposed study theme.

\section{Theoretical Reference}

\subsection{Brief History and Development of Accounting Science}

Today's accounting is an inheritance of the former professionals and users of accounting, its development has been associated with the schools of accounting thought. In this way, the development of Accounting has always been associated with the evolution of society. Many facts are recorded from the beginning of mankind reckoned through centuries of history.

The history of civilization is the greatest witness to the concrete experience of the science of accounting at the beginning of ancient civilization where man already demonstrated accounting control through food control or through drawings found in caves for something that the civilization of the time wanted to record as form of control of their daily life (MARQUES, 2010, page 40).

According to Palhares and Rodrigues, (1990) "The earliest evidence of commercial activity arose in $4500 \mathrm{BC}$, where peoples such as the Assyrians, Chaldeans, and Sumerians of Mesopotamia engaged in agriculture and provided for the creation of cities and the development of commercial activities. The record of these transactions was made on clay plates, where the results obtained in a harvest, objects exchanged, besides taxes and fees collected by the religious sects were verified".

The accounting practices were made as part of the culture, that is, only obeyed the need to control their wealth. In this way they were already being used as an aid in the administration of the patrimony. Economic activities were developing in the cities with the largest market flows in the world. In this way, Bielinski (2011) argues that the need for merchants to improve the quality of the control of their assets arose, Iudícibus (2009, p.16) reports, complementing:

"It is thus easy to understand, going over antiquity, why accounting has flourished as an adult and complete discipline in the Italian cities of Venice, Genoa, Florence, Pisa and others. These cities and others of Europe boiled with mercantile, economic and cultural activity, from the thirteenth century until the beginning of the seventeenth century. They represented what could be more advanced at the time in terms of emerging commercial and industrial ventures. It was during this period, of course, that Pacioli wrote his famous Tractatus de coputis et scripturi, probably the first to give a full and detailed account of accounting".

Thus, there is no way to say exactly how Accounting Science was born or who created it, but its development was stimulated through various changes in society, as society evolved along with commercial relations arose the need for advances in accounting records for meet the demand.

\subsection{The First Signs of Accounting in Brazil and Its Expansion}

In Brazil, accounting began from the colonial period, represented by the evolution of society and the need for accounting controls for the development of trade. The author Bielinski (2011) states that in the nineteenth century merchants learned from the experience gained in the everyday practice of a house of commerce. However, the profession of merchant demanded knowledge that with the entrance of the Colony in the world of the business, was realized the necessity, for the national economy, of an educated and moralized commerce.

In 1869, the Association of Bookkeepers of the Court was created, and was recognized the following year by Imperial Decree No. 4,475, an important fact, since it constituted the bookkeeper, as the first liberal profession in Brazil. The bookkeeper, as the accounting professional was known, was a professional or employee assigned to do the following firm work: drawing up contracts and distrates, controlling the entry and exit of money, through 
payments and receipts, creating correspondence and doing all commercial bookkeeping.

He demanded that the professionals have mastery of the Portuguese and French languages, as well as an improved handwriting. (REIS, SILVA, 2007). "In the period of Colonial Brazil as in 1549 the first appointment made by D. João III for general accountant and bookkeepers occurred." (COELHO, 2000).

In this sense, Favero et al. (2006) describe that accountants were grouped in Brazil according to the level of study in the area: Graduates, through university courses; mid-level technicians, through commercial schools; and bookkeepers, without formal schooling, qualified for mercantile bookkeeping activities, and subsequently regulated as accounting technicians by Law 3.384 / 58 .

Along with the accounting evolution, education in Brazil has undergone changes, with Decree of Law no. 7,988 of September 22, 1945, which creates the course of accounting of higher level in Brazil, with title of superior course of Economic Sciences and Accounting and Actuarial Sciences. The following year, the attributions of accountants and bookkeepers were regulated by Decree-Law no. 9,295, which created the Federal Accounting Council.

These decrees were defined by Martins and Carvalho (2005) as "relevant aspects of the epic of its evolution", since they allowed the first baccalaureate courses in Accounting Sciences in the Country (in the Federal Universities of Minas Gerais, Bahia and Rio Grande do Sul), even though they were still linked to the courses of actuarial sciences, becoming independent only on July 31, 1951, by Law No. 1401.

It is seen that in the year 1945 the first courses of Accounting Sciences in Brazil appear, but only in 1951 the course becomes independent gaining university autonomy. In this way the history of Accounting in Brazil enters a new phase, it is in this context that the upper course of Accounting Sciences arises.

The expansion of accounting education took place through the regulation of the profession, the creation of the first commercial and higher education institutions. From this scenario the evolution of the teaching process and exceptional growth of the most qualified professionals took place.

The accounting in Brazil probably began to be read with the Court's trade class in 1809, which was the Alvares Penteado School of Commerce, and with the transformation of it in 1856 into the Commercial Institute of Rio de Janeiro. Brazil one of the first countries to have an accounting higher education establishment, the Alvares Penteado School of Commerce, established in 1902, the first specialized school in accounting education. (BARROS LEITE, 2005).

This led to the creation of a higher level of accounting through the so-called Trade Classes, which had relevance to the development of the accounting scenario, since they formed the professionals who would act in the records of commercial transactions.

\subsection{Limitation of the Technician in Accounting and Expansion of the Graduation Course}

The provisions of Law 12,249 of 2010 amended Decree-Law 9,295 of 1946, which regulates the accounting profession, determines the creation of the Federal Accounting Council (CFC), and defines the duties of accountants and bookkeepers who, afterwards, became accounting technicians. The new definitions require higher education to obtain registration of the category, but retain the professional prerogatives of the already registered technicians.

Ariel Engster (2014) adds that in the comings and goings of parliamentary procedures, however, Law 12.249, of 2010, began to cover other issues and directly reached the accounting world. One of the many amendments inserted in the original measure determines that, from 2015, only those who have Higher Education can obtain professional registration in Accounting.

The provisions of the above-mentioned law limit the accounting technicians, prohibiting them from obtaining the professional registration, and the technicians already active have not lost their prerogatives of professional right, but from 2015, professionals in technical courses in accounting can only act in the country as accountants through higher education.

In view of this fact, the numbers of those interested in attending the higher courses in Accounting Sciences increased as shown by the data presented by the Ministry of Education (MEC) (2014) and the National Institute of Educational Studies and Research (INEP) September 2014, data from the Census of Higher Education 2013. The Accounting Sciences course is among the most sought after by undergraduate students and occupies the fourth place in the ranking, with 328,031 future professionals. In 2013, 7,509,694 enrollments were made in higher education courses, $7,305,977$ in undergraduate courses and 203,717 in graduate programs.

In addition to this information, the CFC published a note stating that there are 500,000 professionals in Brazil in full 
activity, of which 189,904 are technicians and 311,803 accountants. In addition, the Coordination for the Improvement of Higher Education Personnel (CAPES) accounted in 2010 for 19 public and private institutions offering Stricto Sensu Postgraduate courses. (CFC, 2014.)

With regard to undergraduate education institutions, Bugarim (2014) records that 893 educational institutions offer the Accounting Sciences course in Brazil, of which 103 are public and 790 are private. There is a very significant number of private institutions offering the Accounting Sciences course in relation to a small number of public institutions. The range of bachelors formed by the various HEIs is due to a salary need, a profile more focused on the labor market, aimed at accounting offices and companies, and those interested in the academy in search of better salary conditions end up also dedicating to the liberal labor market, thus restricting their academic activities.

Nossa (1999) in his work explains that:

"Considering this analysis to present the profile of the accounting professional, he observes that one of the great challenges faced in accounting teaching is the full dedication to university activities by the teacher, who seeks better wages and operational conditions, carries out teaching activities only as a supplementary wage and part-time, as their focus is on the labor market mainly as a liberal professional".

Doing so that there is no dedication to scientific research by the same. It should be noted that, given the context presented, the number of researchers and scholars in the accounting area is increasingly reduced due to the lack of due salary recognition. As proof of this, Iudícibus et al. (1998) states that the labor market for the accountant is currently one of the most promising, mainly due to the companies' requirement to improve business control and planning. Thus the accountant must add ethical, prudent and upright behavior to the technical capacities.

With a promising market the graduate in Accounting Sciences will keep his studies linked to employment opportunities and job requirements, probably coming to a postgraduate course to improve what he wants to act.

\subsection{Post-Graduation Lato Sensu and Stricto Sensu}

The Ministry of Education and Culture (2014) states that postgraduate courses cover Master's and Doctoral programs, specialization courses that include designated courses with improvement and others. And they are intended for candidates who are graduates of undergraduate courses and who meet the requirements of educational institutions.

The master's degree, academic master's and doctorate (which is always considered academic) are known as "levels" or "courses" or even "modalities" in the language of Capes. The academic courses aim to train researchers, being the masters the usual way to later move to Doctorate Capes (2005).

\subsubsection{Lato Sensu and Stricto Sensu}

Accounting has a level of knowledge and postgraduate is a significant factor for a qualified professional career. Santos (2000) defines lato sensu post-graduation as the specialization and improvement courses, which usually have a specific technical-professional objective, without covering the total field of knowledge in which the specialty is inserted.

Complementing Machado (2003), confirms that the National Teacher Training Program of Higher Education Institutions (PROCAPIES) divides the lato sensu courses into two modalities: Improvement - these are courses that aim at the expansion and development of knowledge of higher education methodology, scientific methodology and specific content, with a minimum working load of 180 hours. E Specialization - are courses that seek to deepen theoretical and practical knowledge in specific sectors of knowledge, methodology of higher education and scientific methodology, with a minimum workload of 360 hours.

Therefore, it is noted that the Lato Sensu Postgraduate courses aim to meet a specific demand of the labor market, deepening and completing the knowledge, skills and attitudes necessary for professionals according to their technical-professional profile.

The Stricto Sensu Post-Graduation in accordance with the CNE / CSE Resolution No. 1, of April 3, 2001, covers Master Programs, which generally have a duration of two years and as a requirement for approval the defense of a dissertation and the $\mathrm{PhD}$ programs, lasting four years and as a requirement for approval the defense of a thesis. In Brazil there are two types of Masters: Academic Masters that aims to train teachers for high school and higher and the professional Masters that aims at professional qualification at a high level.

The Brazilian Masters Programs are relatively new, in the year 2000, there were only six Programs and one PhD in Accounting Sciences approved by Capes. (Miranda Azevedo and Martins 2010). Reina (2009) evidenced in her research that $63.0 \%$ of the Master's programs in Accounting began to function as of 2004 and there are 19 Masters 
programs in Accounting authorized by Capes until January 16, 2009, three programs focused on master's degree and sixteen programs focused on masters for teaching.

A small number of masters programs can be observed in relation to the number of institutions of graduation, eight hundred and ninety-three, in the accounting area, and of this amount $84 \%$ is focused on professionals interested in teaching, leading to reflection on why would have technical professionals not interested in remaining in the studies after graduation or specialization, one reason being the reduced number of programs. On the other hand, the $\mathrm{PhD}$ programs are defined as Santos (2000) reports as being aimed at providing broad and deep scientific or cultural training through the development of research capacity and the power to create. Bugarim (2014) presents data that calls our attention, where in Brazil today there are 3,264 masters and 275 doctors in accounting.

The number of masters and doctors in the area of accounting is easily detected when the data is verified, that is, of the entrants 7,305,977 in undergraduate courses in Accounting Sciences, a tiny part reaches the master's and doctorate. Raising again a questioning of what would be impacting the formation of masters and doctors in the accounting area, is what this research was proposed.

\section{Methods}

The present article is characterized as a study that is framed in the approach of qualitative and quantitative research, using descriptive and analytical research. The approach to the problem is quantitative and qualitative research. Richardson (1989, p.39) mentions that "studies employing a qualitative methodology can write the complexity of a particular problem, analyze the interaction between variables, understand and classify processes." While Gil (1999) argues that quantitative research considers that everything is quantifiable, which means translating opinions and numbers into information that will be classified and analyzed.

As for the general objective, the research is classified as descriptive, for Gil (1999) the descriptive research has as main objective to establish relations among the variables, to determine the population or phenomenon. According to Rodrigues (2006, p.90). In the descriptive research, the researcher studies the relations between the variables of a certain phenomenon without manipulating them, that is, it establishes and evaluates the relations as the variables manifest themselves spontaneously. For Thomas and Nelson (1996) analytical research involves the in-depth study and evaluation of available information in an attempt to explain the context of a phenomenon. The investigator is more concerned with finding facts that will provide greater understanding and significance of past events to explain the current situation or current state of the phenomenon studied.

The procedures are those that "refer to the way in which the study is conducted and, therefore, the data are obtained". (Beuren, 2008, p.83). For Cervo and Bervian (1983), the bibliographical research responds to a problem from theoretical references. In order to reach this objective the research was carried out, a bibliographical research was carried out, with the survey of existing theories, regulations and concepts on the subject.

A field survey was carried out, with data and information collected in three universities: at the undergraduate level, 80 undergraduates were interviewed at the Universidade Estadual de Goiás (UEG), Campus Jaraguá-GO, at the MSc level, 29 universities Federal University of Goiás (UFG), Samambaia Campus and Federal University of Santa Catarina (UFSC), University Campus - Trindade, and at the Doctoral level $18 \mathrm{PhD}$ students were interviewed at the University of Brasília (UNB).

The research was developed based on the data provided by the research sources, this information was useful for the assembly of the demonstrative tables, where the research was carried out with survey in the sites of the institutions and edicts of the masters and doctoral programs, evidencing the number of institutions which are part of the graduate programs in Brazil and the number of programs and number of places. In addition, it was researched with the University of Minho - School of Economics and Management and Hotcourses Brazil, questioning about the graduate programs in Accounting in the United States, Australia and Canada, which made possible the preparation of the comparative programs of post -University graduate.

After data collection, it was possible to consolidate and compare the data, thus producing information that allowed the analysis, interpretation and discussion of the data on the development of accounting higher education in Brazil, encompassing the context of graduation to the doctorate, raising data that show the reality of each level of education.

\section{Results and Discussion}

Number tables consecutively in accordance with their appearance in the text. Place a table's caption above the table's body and its description below the body. Avoid vertical rules. Be sparing in the use of tables and ensure that the data presented in tables do not duplicate results described elsewhere in the article. 
Table 1. Higher education institutions offering stricto sensu postgraduate programs in the course of accounting sciences in brazil

\begin{tabular}{|c|c|c|c|}
\hline Program & Higher Education Institutions & Brazilian state & Type of Course Stricto Sensu \\
\hline Accounting Sciences & Federal University of Bahia (UFBA) & BA & Academic Master \\
\hline Accounting Sciences & Federal University of Paraná (UFPR) & PR & Master's/Doctoral degree \\
\hline Accounting Sciences & Federal University of Santa Catarina (UFSC) & $\mathrm{SC}$ & Master's/Doctoral degree \\
\hline Accounting Sciences & University of Brasilia (UNB) & DF & Master's/Doctoral degree \\
\hline $\begin{array}{l}\text { Accounting and } \\
\text { Controlling Sciences }\end{array}$ & Federal University of Amazonas (UFAM) & $\mathrm{AM}$ & Professional Master's Degree \\
\hline $\begin{array}{l}\text { Controllership and } \\
\text { Accounting Sciences }\end{array}$ & University of Sao Paulo (USP) & SP & Master's/Doctoral degree \\
\hline $\begin{array}{l}\text { Controllership and } \\
\text { Accounting Sciences }\end{array}$ & $\begin{array}{l}\text { University of São Paulo - Campus Ribeirão } \\
\text { Preto (USP/RP) }\end{array}$ & SP & Master's/Doctoral degree \\
\hline Accounting Sciences & Federal University of Espírito Santo (UFES) & ES & Academic Master \\
\hline Accounting Sciences & $\begin{array}{l}\text { Capixaba Institute for Research in Accounting, } \\
\text { Economics and Finance (FUCAPE / ES) }\end{array}$ & ES & $\begin{array}{l}\text { Master's/Doctoral degree } \\
\text { Professional Master's Degree }\end{array}$ \\
\hline Accounting Sciences & Federal University of Minas Gerais (UFMG) & MG & Academic Master \\
\hline Accounting Sciences & $\begin{array}{l}\text { Capixaba Institute for Research in Accounting, } \\
\text { Economics and Finance (FUCAPE / RJ) }\end{array}$ & RJ & Professional Master's Degree \\
\hline Accounting Sciences & Federal University of Uberlândia (UFU) & MG & Master's/Doctoral degree \\
\hline Accounting Sciences & Federal University of Pernambuco (UFPE) & $\mathrm{PE}$ & Master's/Doctoral degree \\
\hline Accounting Sciences & Federal University of Rio de Janeiro (UFRJ) & RJ & Master's/Doctoral degree \\
\hline Accounting Sciences & University of the State of Rio de Janeiro (UERJ) & RJ & Academic Master \\
\hline Accounting Sciences & $\begin{array}{l}\text { University of the Rio dos Sino Valley } \\
\text { (UNISINOS) }\end{array}$ & $\mathrm{RS}$ & Master's/Doctoral degree \\
\hline Accounting Sciences & Regional University of Blumenau (FURB) & $\mathrm{SC}$ & Master's/Doctoral degree \\
\hline Accounting Sciences & Mackenzie Presbyterian University (UPM) & SP & Master's/Doctoral degree \\
\hline Accounting Sciences & $\begin{array}{l}\text { University Center Alvares } \\
\text { (UNIFECAP) }\end{array}$ & SP & Academic Master \\
\hline $\begin{array}{l}\text { Accounting and } \\
\text { Actuarial Sciences }\end{array}$ & $\begin{array}{l}\text { Pontifical Catholic University of São Paulo } \\
\text { (PUC / SP) }\end{array}$ & SP & Academic Master \\
\hline Accounting Sciences & Federal University of Paraíba (UFPB) & PB & Master's/Doctoral degree \\
\hline Accounting Sciences & State University of Maringá (UEM) & PR & Academic Master \\
\hline Accounting Sciences & $\begin{array}{l}\text { Federal University of Rio Grande do Norte } \\
\text { (UFRN) }\end{array}$ & RN & Academic Master \\
\hline Accounting Sciences & $\begin{array}{l}\text { State University of Western Paraná } \\
\text { (UNIOESTE) }\end{array}$ & PR & Academic Master \\
\hline Accounting Sciences & $\begin{array}{l}\text { Community University of the Region of } \\
\text { Chapecó (UNOCHAPECO) }\end{array}$ & $\mathrm{SC}$ & Academic Master \\
\hline Accounting Sciences & Federal University of Goiás (UFG) & GO & Academic Master \\
\hline
\end{tabular}

Source: Adapted Anpcont and Anpad (2017).

It can be observed a greater location of Masters in the Southeast Region, specifically in the State of São Paulo, and in other States with less than half remaining available in other areas of the Brazilian territory. It understands through the table that of the 26 higher education institutions that offer Master's and Doctoral programs, 21 are public and 05 are private, respectively public institutions represent $80 \%$, while private institutions $20 \%$. It is evident that at the stricto sensu level there are more public than private universities, the opposite scenario of graduation, where 893 institutions are responsible for baccalaureate education in accounting, of which 103 are public $12 \%$ and 790 private $88 \%$.

In this context, Burton (2009) argues about the expansion of private HEI, emphasizing that the expansion was observed from the moment that a strong government incentive occurred and led to a disproportionate growth of the Brazilian private university sector that was higher than that of public HEIs. In turn, public HEIs continued to figure as coadjuvants in the training of academics in accounting.

It can be seen that the private sector increased its participation in higher education at the undergraduate level, 
predominating in the participation of private HEIs in this modality, who became the major responsible for the graduation of undergraduates, not giving so much emphasis to the investment in Masters and PhD courses .

One of the issues addressed here was the few master's and doctoral programs in the accounting area, as well as the concentration in some states that hinder access. The following table shows the number of vacancies in the 26 Institutions that offer Academic Master, Professional Master and Doctorate.

Table 2. Number of vacancies higher education institutions offer at masters and phd levels

\begin{tabular}{|c|c|c|c|c|}
\hline $\begin{array}{c}\text { Higher Education } \\
\text { Institutions }\end{array}$ & $\begin{array}{c}\text { Number of vacancies } \\
\text { Academic Master's }\end{array}$ & $\begin{array}{l}\text { Number of vacancies } \\
\text { Professional Master's }\end{array}$ & $\begin{array}{c}\text { Number of vacancies } \\
\text { Doctorate }\end{array}$ & Year \\
\hline UFBA & 15 vacancies & ----- & ----- & 2016 \\
\hline UFPR & 24 vacancies & ----- & 06 vacancies & 2016 \\
\hline UFSC & 25 vacancies & ----- & 13 vacancies & 2016 \\
\hline UNB & 17 vacancies & ----- & 11 vacancies & 2016 \\
\hline UFAM & ----- & 30 vacancies & ----- & 2013 \\
\hline USP & 20 vacancies & ----- & 15 vacancies & 2016 \\
\hline USP/RP & 15 vacancies & ------ & 11 vacancies & 2016 \\
\hline UFES & 22 vacancies & ----- & ----- & 2016 \\
\hline FUCAPE/ES & 05 vacancies & 19 vacancies & 05 vacancies & 2015 \\
\hline UFMG & 16 vacancies & ----- & ----- & 2016 \\
\hline FUCAPE/RJ & 20 vacancies & -------- & & \\
\hline UFU & 20 vacancies & ----- & 10 vacancies & 2017 \\
\hline UFPE & 10 vacancies & ----- & ----- & 2016 \\
\hline UFRJ & 45 vacancies & ----- & 25 vacancies & 2016 \\
\hline UERJ & 20 vacancies & ----- & ----- & 2016 \\
\hline UNISINOS & 13 vacancies & ----- & 06 vacancies & 2016 \\
\hline FURB & 20 vacancies & ----- & 06 vacancies & 2016 \\
\hline UPM & ----- & 15 vacancies & ----- & 2016 \\
\hline UNIFECAP & 19 vacancies & ----- & ----- & 1999 \\
\hline PUC/SP & 15 vacancies & ----- & ----- & 2016 \\
\hline UFPB & 16 vacancies & ------ & 08 vacancies & 2016 \\
\hline UEM & 18 vacancies & ------- & ----- & 2016 \\
\hline UFRN & 10 vacancies & ------- & ------- & 2016 \\
\hline UNIOESTE/PR & 15 vacancies & -------- & -------- & 2016 \\
\hline UNOCHAPECÓ/SC & 20 vacancies & --------- & -------- & 2016 \\
\hline UFG & 20 vacancies & -------- & -------- & 2016 \\
\hline
\end{tabular}

Source: prepared by authors (2017)

After a thorough analysis of all the master's and doctoral programs, it was possible to obtain the number of vacancies offered in each program, and the academic master's degrees totaled 440 places, and the professional master's programs totaled 64 places, and the programs doctoral degree totaled 106 places. In view of the data collected, it is clear that there is a reduced number of vacancies offered for the master's degree and a lower number for the doctorate, which results in the data of few masters $(3,264)$ and doctors (275) in the accounting area that exist in Brazil.

This fact registered by the CFC (2016) shows that post-graduation education in Brazil has been experiencing exceptional growth, which represents an auspicious gain in professional and academic quality. In the accounting area, however, this phenomenon has not been occurring in equal proportion. Although the Accounting Sciences course is in good demand, there is a small number of Masters courses in Accounting in relation to the number of teachers working in the country's educational institutions. Ferreira and Hillen (2015) present a criticism when they say that few courses imply to understand few vacancies and, consequently, few teachers researching and thinking about aspects specific to the field itself.

There are two situations: first, we have few programs and still few have a reduced number of places and, according to the absence of more programs with more vacancies, it may be possible to address the lack of governmental 
incentive towards higher education institutions at Masters and Doctorate degree.

By identifying the 26 institutions that offer the master's and doctoral programs, the lines of research were laid out, through the edicts of each selection process.

Table 3. Lines of research found

\begin{tabular}{|c|c|c|c|}
\hline $\begin{array}{l}\text { Higher Education } \\
\text { Institutions }\end{array}$ & Research Lines & $\begin{array}{l}\text { Brazilian } \\
\text { state }\end{array}$ & $\begin{array}{l}\text { Type of Course Stricto } \\
\text { Sensu }\end{array}$ \\
\hline UFBA & Financial Accounting and Management Accounting & $\mathrm{BA}$ & Academic Master \\
\hline UFPR & $\begin{array}{l}\text { Financial Accounting and Management Accounting and } \\
\text { Finance }\end{array}$ & PR & Master's/Doctoral degree \\
\hline UFSC & $\begin{array}{l}\text { Management Control and Performance Evaluation, } \\
\text { Financial Accounting and Accounting Research }\end{array}$ & $\mathrm{SC}$ & Master's/Doctoral degree \\
\hline UNB & $\begin{array}{l}\text { Accounting and Financial Market, Impacts of } \\
\text { Accounting in the Public Sector, Organizations and } \\
\text { Society }\end{array}$ & DF & Master's/Doctoral degree \\
\hline UFAM & $\begin{array}{lcc}\text { Controllership and } & \begin{array}{c}\text { Organizational } \\
\text { Organizational }\end{array} & \begin{array}{c}\text { Accounting, } \\
\text { Strategic }\end{array}\end{array}$ & AM & Professional Master's \\
\hline USP & $\begin{array}{l}\text { Socio-Environmental Development Management } \\
\text { Financial Accounting, Controllership and Finance }\end{array}$ & SP & Master's/Doctoral degree \\
\hline USP/RP & Financial Accounting, Controllership and Finance & SP & Master's/Doctoral degree \\
\hline UFES & $\begin{array}{l}\text { Accounting and Finance, Organizational Accounting and } \\
\text { Society }\end{array}$ & ES & Academic Master \\
\hline FUCAPE/ES & $\begin{array}{l}\text { Finance and Business Assessment, Strategic Public and } \\
\text { Private Management }\end{array}$ & ES & $\begin{array}{l}\text { Master's/Doctoral degree } \\
\text { Professional Master's }\end{array}$ \\
\hline UFMG & Financial Accounting, Controllership and Finance & MG & Academic Master \\
\hline FUCAPE/RJ) & $\begin{array}{l}\text { Finance and Business Assessment, Strategic Public and } \\
\text { Private Management }\end{array}$ & RJ & Professional Master's \\
\hline UFU & Financial Accounting, Controllership and Finance & MG & Master's/Doctoral degree \\
\hline UFPE & Accounting information for internal and external users & PE & Master's/Doctoral degree \\
\hline UFRJ & Accounting and Society & RJ & Master's/Doctoral degree \\
\hline UERJ & Not found & RJ & Academic Master \\
\hline UNISINOS & Management Control, Accounting and Finance & $\mathrm{RS}$ & Master's/Doctoral degree \\
\hline FURB & $\begin{array}{l}\text { Financial Accounting, Management Accounting and } \\
\text { Strategy and Competitiveness }\end{array}$ & $\mathrm{SC}$ & Master's/Doctoral degree \\
\hline UPM & Strategic Finance and Business Development & SP & Master's/Doctoral degree \\
\hline UNIFECAP & Applied Controlling and Financial Accounting & SP & Academic Master \\
\hline $\mathrm{PUC} / \mathrm{SP}$ & $\begin{array}{l}\text { Accounting and Auditing, Economic Control of Finance } \\
\text { Management }\end{array}$ & SP & Academic Master \\
\hline UFPB & Accounting information for external and internal users & PB & Master's/Doctoral degree \\
\hline UEM & $\begin{array}{l}\text { Management Accounting and Accounting for external } \\
\text { users }\end{array}$ & PR & Academic Master \\
\hline UFRN & Impacts of Accounting on Organizations and Society & $\mathrm{RN}$ & Academic Master \\
\hline UNIOESTE & $\begin{array}{l}\text { Management Accounting and Control in Organizations, } \\
\text { Financial Accounting }\end{array}$ & PR & Academic Master \\
\hline UNOCHAPECÓ & Management and Innovation in Productive Chains & $\mathrm{SC}$ & Academic Master \\
\hline UFG & Financial Accounting and Controlling e finanças. & GO & Academic Master \\
\hline
\end{tabular}

Source: Prepared by authors (2017)

In the collection of data it was also possible to identify the lines of research through a detailed analysis in all the edicts of the master's and doctoral programs, the areas that stand out most are Financial Accounting, Controllership and Finance. The majority of the programs offer two lines of research, the vacancies are divided between both, at the time of registration the candidate must, necessarily, indicate the line of research to which his Research Proposal is linked. 
In this way the Master's and Doctorate are stages of improvement that are used not only for academic career but also for the corporate world of the organizations, the scientific knowledge allows a greater capacity to interpret complex problems and offer solutions that are viable of greater efficiency of organizations to understand the scientific method take solutions that are necessary for organizations.

In order to obtain a better foundation, research was carried out with International Universities to show if the other countries have the same Brazilian scenario, in relation to the number of graduate programs in accounting, being they reference in qualification of professionals in the course of accounting sciences.

The first program analyzed was a Ph.D. in Accounting in the United States. It was created by the University of Illinois at Urbana - Champaign in 1938, to reflect a new vision in the teaching of Accounting (Bedford, 1997). It is noteworthy that, unlike the Brazilian context, the United States had already trained more than 6,000 $\mathrm{PhDs}$ in Accounting until 2005 (Murcia, Borba and Ambrósio, 2007).

A survey was carried out with the University of Minho - University of Minho - School of Economics and Management (2016) and at the Universities of Canada, United Kingdom and the United States according to Hotcourses UK (2016). Higher education institutions responsible for offering postgraduate accounting programs in both countries. After contacting us through e-mails and surveys on the websites of the universities of the mentioned countries, there were found in Australia 35 universities, Canada 27 universities, United Kingdom 152 universities, United States 490 universities that are responsible for offering Stricto Sensu courses in Accounting, with greater predominance in Professional Master's Degree.

Another information obtained in research is that the Post-Graduate in the countries surveyed is performed differently than those in Brazil, where the Masters and Doctoral programs in Brazil work in series, while abroad they are parallel. This means that while in Brazil the student must first complete the Master's course and then start his doctorate, in the countries surveyed he can start the $\mathrm{PhD}$ without having the title of Master. Below is a comparative table showing the countries involved in the research, as well as the number of higher education institutions with the number of programs offered.

Table 4. Quantitative master's and $\mathrm{PhD}$ programs in accounting in the researched countries

\begin{tabular}{ccc}
\hline Countries & $\begin{array}{c}\text { Quantities of Institution of Higher } \\
\text { Education }\end{array}$ & Number of Programs \\
\hline Australia & 35 & 182 \\
Brazil & 26 & 41 \\
Canada & 27 & 67 \\
USA & 490 & 831 \\
United Kingdom & 152 & 787 \\
\hline
\end{tabular}

Source: Prepared by authors (2017)

The international field shows superior data regarding the number of programs offered, the United States leads with 490 universities and 397 offer Masters courses and 93 offer a doctorate course, providing in the country a great number of masters and doctors, since there are 831 Software. The UK offers a very high number of 787 programs, predominance of the Professional Master. Australia has a high number of programs offered. It is interesting to note that it has 35 IES and offers 182 programs, a reality also observed in Canada, which obtains 67 programs in the 27 IES. Finally, Brazil has only 41 programs between Masters and PhDs in the 26 existing institutions, a much smaller amount when compared to other countries.

It should be noted that in Brazil, in addition to being new, the programs are also in a very small amount, today in Brazil according to the MEC (2014), the Accounting Sciences course has 328,031 future professionals if we compare with the 26 post- with only 440 Masters and only 106 doctoral positions, so one can imagine the immense difficulty and challenges that will be encountered by recent students to have the opportunity to enter a higher academic level of Accounting in the case of Masters or PhD.

Master's and PhD programs need the same incentive that the government has taken to undergraduate courses, so that higher education institutions offer more programs and higher numbers of vacancies and new institutions are also 
promoters. In this context, if Brazil counts on few programs, consequently, it will be forming a few masters and doctors where it is limited to new openings of new programs, perhaps this is one of the main reasons for few teachers and doctors in accounting in the country.

This segmentation contemplates the results of the closed and optional questionnaires divided between the three levels of education, with three objective questions, created through the information and data found and evidenced in the research. Aiming now to understand the understanding of academics regarding the number of programs and places in each Brazilian selection process compared to the foreign countries presented. The data collection lasted 45 days, developed through an online platform. The questionnaire was applied to HEI at the undergraduate, master's and doctoral levels, obtaining the following participations: 80 Graduates from the State University of Goiás (UEG), Jaraguá-GO Campus, 29 Masters of Universities: Federal University of Goiás (UFG), Campus Samambaia and Federal University of Santa Catarina (UFSC), Rector Campus João David Ferreira Lima and $18 \mathrm{PhD}$ students from the University of Brasília, Campus Darci Ribeiro. Allowing for the analyzes below.

The question of number 01 presents the information of the comparative of the programs illustrated in Table 04, being questioned the understanding of the academics in relation to a comparative of the Brazilian programs with foreigners, aiming to identify if there is an agreement or not of the academics with the objective of the research which is proportional to the expansion of Brazilian programs.

- Question 01: Brazil has 26 universities responsible for offering programs of Stricto Sensu in Accounting, smaller number when compared to countries like Australia, where there are 35 universities, the United States with 490 universities and also the United Kingdom with 152 universities. Given this information, do you agree that Brazilian Postgraduate programs should be expanded, since graduation has also been gaining exceptional growth?

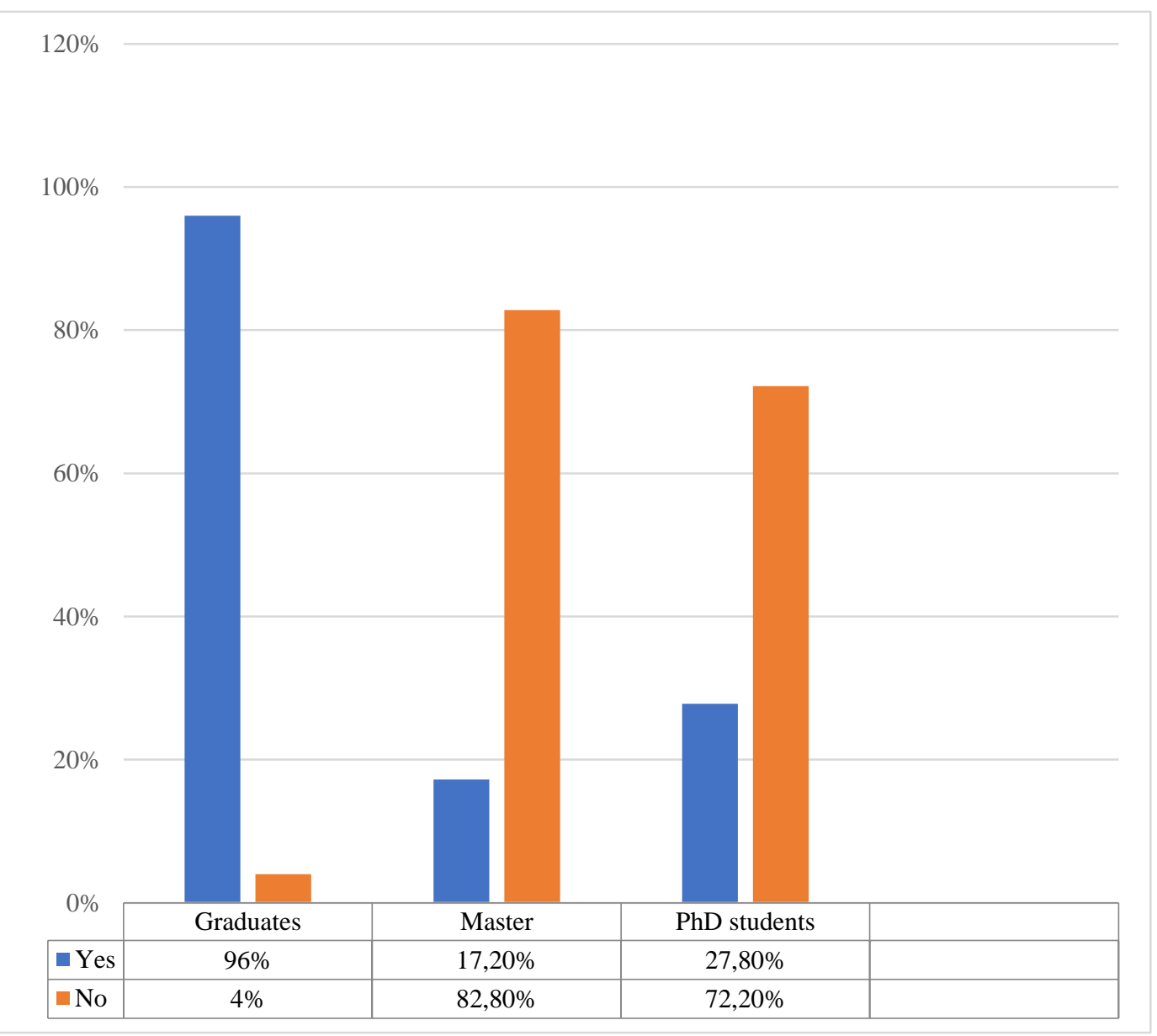

Figure 1. Comparison of stricto sensu programs

Source: Prepared by authors (2017) 
It is clear that Undergraduates fully agree with the expansion of the programs, a fact that is probably generated by the desire for continuity of studies, given the greater number of programs and vacancies. On the other hand, the Masters and $\mathrm{PhD}$ students have the opposite view of undergraduates in that the numbers of Brazilian programs do not need to be expanded.

Regarding the vacancies offered in the Masters and Doctoral programs, the questionnaire sought to evaluate the opinion of the respondents regarding the number of vacancies offered by the selective processes of the programs.

- Question 02: Since most of the programs opt for annual selective processes, and at the levels of Academic, Professional and Doctorate, the vacancies are at least ten and at most twenty, how do you rate that amount?

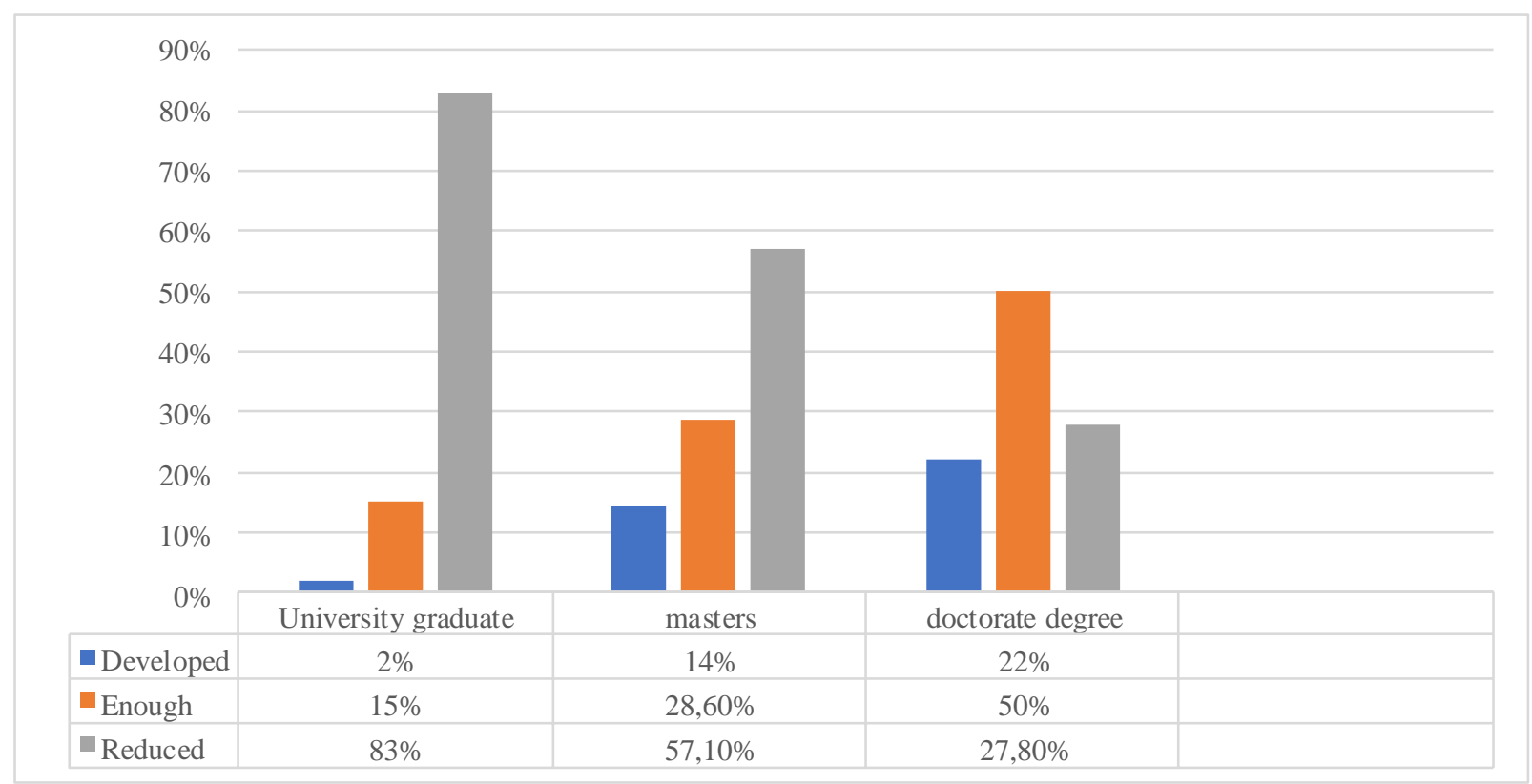

Figure 2. Number of stricto sensu brasileira program vacancies

Source: Prepared by Authors (2017)

We perceived diversified opinions among those surveyed, where the degree students hold the view that the number of vacancies offered is extremely low, with $83 \%$, the masters placed more emphasis also on the reduced option with $57 \%$, despite finding $28 \%$ sufficient, and finally and totally adverse the doctoral students consider the sufficient waves, showing a different interpretation to the others.

Finally, he was asked about the level of difficulty in continuing the studies undergraduates will hold when they finish their studies in the Brazilian scenario of offers of programs and vacancies.

- Question 03: The president of the Brazilian Academy of Accounting Sciences, on the occasion of the opening of the 9th National Meeting of Coordinators and Professors of the Accounting Sciences course in 2014, recorded that there are 893 institutions of higher education at the undergraduate level, comparing this data with the number of institutions of the graduate programs at the stricto sensu level, which are 26 , include the difficulty that newly graduated students will have in order to be able to continue their studies immediately. In this context answer the following about the level of difficulty. 


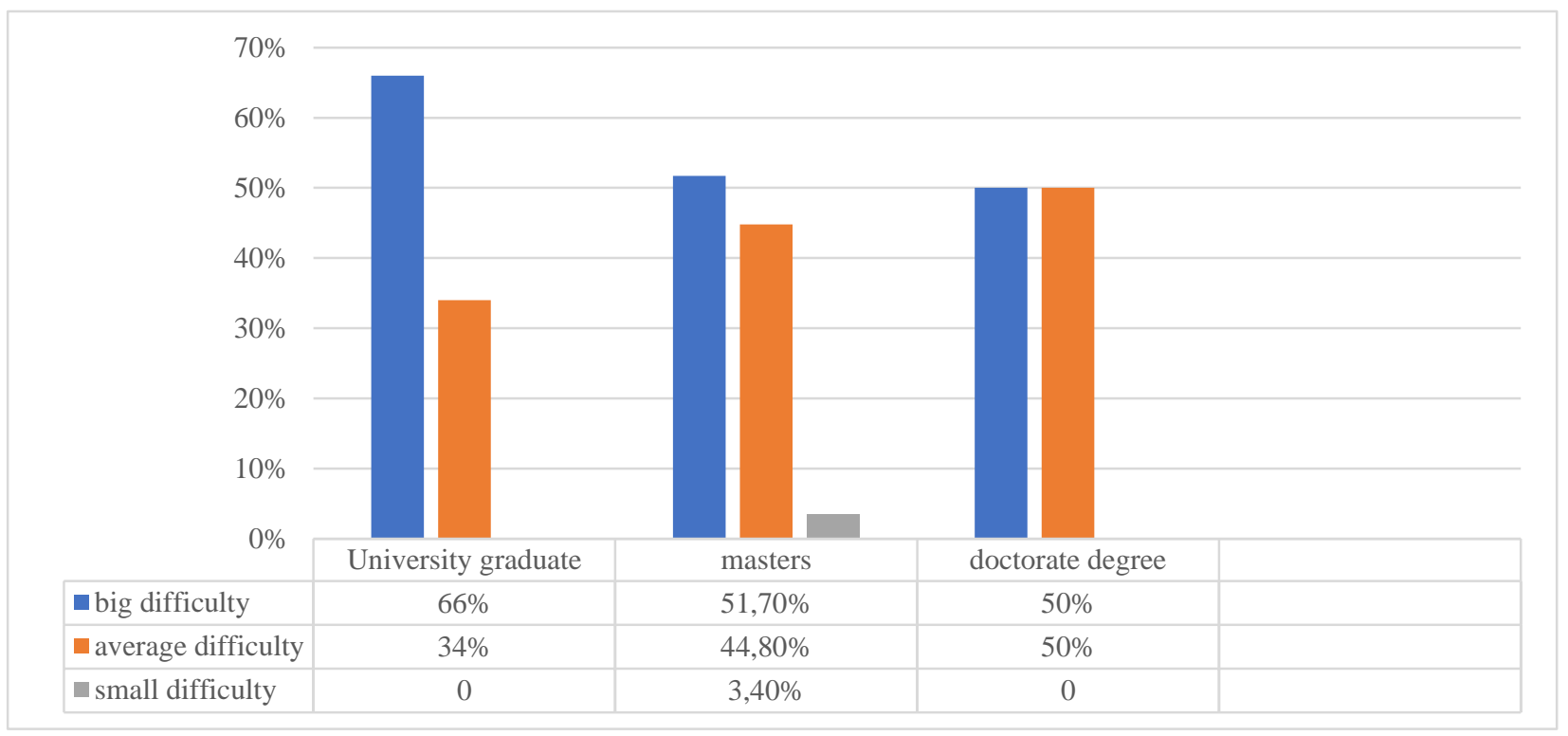

Figure 3. Difficulty of graduates in inserting into stricto sensu brasileiros programs

Source: Prepared by authors (2017)

It is noteworthy that all three levels of education acknowledge the great difficulty that the recent graduate in Accounting, undergraduate level, will have to enter Master's or Doctorate programs due to the reduced number of programs and vacancies. It should be noted that there was a division of opinions with the same percentage by the doctoral students between great and medium difficulty, which does not affect the interpretation that graduates will in fact have difficulties in continuing their studies at Masters and PhD levels.

Thus, graduation is growing and large are the amounts of public or private institutions that offer, the course of Accounting as evidenced previously, being also fundamental and necessary to develop in quantities the programs and vacancies of Stricto Sensu Postgraduate.

\section{Conclusion}

In view of the theoretical and analytical evidences through the research, it was possible to achieve the general objective proposed, with regard to the analysis and disclosure of the context of the development of accounting teaching in Brazil, at the Stricto Sensu Undergraduate and Postgraduate level, emphasizing the Master and Doctorate.

It was possible to identify how some relevant events occurred in the scenario of accounting higher education expanded in the graduation, through the government incentives, the index increase the demand for the course of Accounting Sciences and also by the amount of future new professionals, but to some extent in level of Post-graduation was identified a low amount of programs offering at stricto sensu level. Consequently if accounting today suffers from the lack of teachers this becomes the main reason for the fact that today there are a large number of graduates, but in return a small level of masters and doctors. Complementing this thinking the author Beyer (2010) states that higher education faces a serious and growing lack of teachers in the area of Accounting.

In that sense, if we have few programs, consequently we will have few masters and few doctors affecting the opening of new programs. In applied research it was first evident that only undergraduates considered that the Brazilian Postgraduate programs should be expanded, as opposed to this understanding the masters and doctoral students. When questioned about the number of jobs offered by Stricto Sensu, graduates and masters ranked as reduced and doctoral candidates as sufficient. And finally, if the question arises that if the recent graduates in Accounting will have difficulty in continuing their studies at Masters and Doctoral levels, all have agreed that they will have great difficulties.

Therefore, it is necessary to carry out strategies and incentives that reach the Masters and Doctoral Programs, in order to increase the programs and vacancies offered. Providing opportunities as more vague and more programs have allowed greater access through interested academics. Generating the development of the Stricto Sensu level, 
overcoming limits and reaching national boundaries with program openings in state regions that are not yet offering Stricto sensu degree programs.

Regarding the limitations of this research, it is worth noting the difficulty of participating with the masters and doctoral students, but possibly we would obtain the same results if there were more participants, it was possible to obtain pertinent and suitable considerations for the study with the number of participants. The subject proposed in this study is extremely relevant and informative, related to the activities of the academy of studies and research in Accounting, and is therefore susceptible to future research, considering the study as a fact of reflection and contribution on the reality of the Stricto Sensu postgraduate scenario Brazilian.

\section{References}

Ariel E. (2014). The future of the accounting technician in sheikh - Jornal do Comércio. Retrived from http://jcrs.uol.com.br/mob/noticia.php?codn=162852

Australian Universities. (2016). Questionnaire on the number of higher education institutions responsible for offering postgraduate accounting programs in Australia. Retrived 29 May 2016, from http://www.australianuniversities.com.au/courses/australia/postgraduate/accounting/campus/c/d/pg-accounting/

Bedford, Norton M. (1997). A History of Accountancy: At the University of Illinois, Urbana-Champaign. Center of International Education and Research in Accounting, Champaign, IL.

Beuren, I. M. (2003). Methodology of research applicable to social sciences. In BEUREN, I. M. (org) How to elaborate monographic works in accounting: theory and practice. São Paulo: Atlas.

Beyer, Brooke, Herrmannn, Don, Meek, Gary K., \& Rapley, Eric T. (2010). What it Means to be an Accounting Professor: a concisecareerguide for doctoralstudents in accounting. Issues in Accounting Education, 25(2), 227-244.

Bielinski, A. C. (2011). Professional Education in the nineteenth century - Commercial Course of the Lyceum of Arts and Crafts: a case study. Retrived 13 May 2016, from http://www.senac.br/BTS/263/boltec263e.htm

Brasil. (1870). Decree of Law no. 4,475, dated February 18, 1870. Created the Association of Bookkeepers of the Court.

Brazil. (1945). Decree of Law no. 7,988, dated September 22, 1945, which created the course of accounting of higher level in Brazil.

Brazil. (1951). Law no. 1,401, dated July 31, 1951. It includes, in the course of economic sciences, the History, General and Brazilian Economy, and unfolds the course of accounting and actuarial sciences.

Brazil. (1958). Law No. 3,384, of April 28, 1958. Provides for the regulation of technical bookkeeping in accounting.

Brazil. (2010). Law \# 12,249, of June 11, 2010. It defines that only those who have Higher Education can obtain professional registration in Accounting.

Brazil. (2016). Ministry of Education and Culture. Postgraduate latu sensu and stricto sensu. Retrived 26 May 2016, from http://portal.mec.gov.br/sesu/index.php?option=com_c\%20ontent\&task=view\&id=934\&Itemid=549\#nn

Bugarim, M.C. C. (2014). X National Meeting of Coordinators and Professors of the Course of Accounting Sciences. Retrived 25 Apr 2016, from http://portalcfc.org.br/noticia.php?new $=17352$

Burton, G. J. S. (2009). Social democracy in LatinAmerica: Policymakersandeducationreform in Braziland Chile. Doctoral Thesis, Department of Geography / London School of Economics and Political Science, London.

CAPES. (Coordination for the Improvement of Higher Education Personnel, 2015). Difference between Academic and Professional Masters. Retrived 10 Jul 2016, from http://www.capes.gov.br/acessoainformacao/frequentesques/avaliacao-de-pos-graduacao/7419-professional-mo nitoring

CAPES. (Coordination for the Improvement of Higher Education Personnel, 2005). Academic Courses. Retrived 3 Jul 2016, from https://www.capes.gov.br/images/stories/download/artigos/Artigo_30_08_07.pdf

Cervo, A.L., \& Bervian, P.A. (1993). Scientific Methodology (3nd ed.). São Paulo: McGraw-Hill do Brasil

CFC. (2016). (Federal Accounting Council). Number of Enrolled in Accounting. Retrived 22 May 2016, from http://www.portalcfc.org.br/noticia.php?new=17147

Coelho, C. U. (2000). The accounting technician and the labor market: historical context, current situation and perspectives. Senac Technical Bulletin, 26(3).

Favero, H. L. (2006). Accounting: theory and practice (4th ed). São Paulo: Atlas, v. 1, p.282. 
Ferreira. M. M., \& Hiller. C. (2015). Contributions of the stricto sensu postgraduate course for the teaching of teaching of accounting teachers. Retrived 29 May 2016, from http://www.periodicos.uem.br/ojs/index.php/Enfoque/article/view/29031

Gil, A.C. (1999). Methods and techniques of social research (5th ed.). São Paulo: Atlas.

Hotcourses Brasil. (2016). Questionnaire on the number of higher education institutions responsible for offering postgraduate accounting programs in the UK. Retrived May 29, 2016, from http://www.hotcourses.com.br/study/training-degrees/uk/postgraduate/accounting-courses/loc/210/slevel/3/cgor $\mathrm{y} / \mathrm{d} 1-3 / \mathrm{sin} / \mathrm{ct} / \mathrm{programs} . \mathrm{html}$

Hotcourses Brasil. (2016). Questionnaire Regarding the number of higher education institutions responsible for post-graduate accounting offers in Canada. Retrived 29 May 2016, from http://www.hotcourses.com.br/study/training-degrees/canada/postgraduate/accounting-courses/loc/32/slevel/3/c gory $/ \mathrm{d} 13 / \mathrm{sin} / \mathrm{ct} /$ programs.html\#search \& parentQualId=3\&catCode= D1-3 \& countryIds $=32 \&$ filterCntrds $=32$ $\&$ provCntryId $=32 \&$ restRefineFlag $=\mathrm{Y} \&$ pageNo $=3 \&$ urlcatId $=$ D $1-3 \&$ provCntryId $=32$

Hotcourses Brasil. (2016). Questionnaire Regarding the number of higher education institutions responsible for offering post-graduate programs in accounting in the United States. Retrived May 29, 2016, from https://www.hotcourses.com.br/study/trainingdegrees/international/postgraduate/accounting-courses/slevel/3/cg ory/d1-3/sin/ct/programs.html

Iudicibus, S. (1998). (Coord.). Team of Prof. FEA / USP. Introductory Accounting (9th ed.) São Paulo: Atlas, P. 293.

Iudicibus, S. (2009). Theory of Accounting (9th ed.). São Paulo: Atlas.

Leite, C. E. B. (2005). The Evolution of Accounting Sciences in Brazil (1st ed.). Editora FGV.

Machado, M. R. (2003). Concept, origin and evolution of the post-graduation lato sensu. Paraíba. 2003. Retrived 10 jun. 2016, from http://www.unb.br/cca/posgraduacao/mestrado/dissertacoes/mest_dissert_017.pdf

Marques, W. L. (2010). General Accounting I. Paraná: Gráfica Vera Cruz.

Martins, E., \& Carvalho, L. N. (2005). Accounting: relevant aspects of the epic of its evolution. Revista Contabilidade Financeira - USP. São Paulo, n. 38, pp. 7-19.

Miranda, G.J., Azevedo, R.F., \& Martins, G. (2010). Theses of Theses in Accounting. In USP Congress of Controllership and Accounting, 10., São Paulo. Anais ... São Paulo: FEA / USP, 2010.

Nossa V. (1999). Faculty formation of undergraduate courses in accounting in Brazil: a critical analysis. Book of Studies, n. 21, pp. 01-20.

Palhares, A., \& Rodrigues, L. C. (1990). Introduction to Accounting. São Paulo: Scipione Publishing House.

Reina, D. (2009). Mapping of scientific production in intellectual capital: an epistemological study in the national and international context, based on the perspectives proposed by Marr (2005), from 1994 to 2008. Dissertation (Master in Accounting). 2009. 337 f. Federal University of Santa Catarina (UFSC), Florianópolis.

Reis, A.J., \& Silva, S. L. (2007). The History of Accounting in Brazil. 2007. 13 f. Dissertation (Graduation in Accounting Sciences). UNIFACS. Sao Paulo.

Richardson, R.J. (1989). Qualitative research method. Social research: methods and techniques. São Paulo: Atlas.

Rodrigues, A.J. (2006). Scientific methodology. Complete and essential for university life. São Paulo: Avercamp Publishing House.

Santos, A.C. P. (2000). Sectoral analysis: higher education (4th ed.). Gazeta mercantil, v. 2. pp. 238-239. SÁ, A. L. Theory of Accounting. São Paulo: Atlas, 2008.

Thomas, J.R., \& Nelson, J.K. (1996). Research Methods in Physical Activity (3nd ed.). Champaign: HumanKinetics. 